\title{
Pre-purchase information search and consumer satisfaction: replication and extension
}

\author{
D. Rousseau
}

Department of Industrial and Organizational Psychology, University of Port Elizabeth, Port Elizabeth

In this paper the author examines consumer satisfaction with major household appliances and its determining factors. Hypotheses relating to pre-purchase information search and product satisfaction as well as previous satisfactory store experiences and subsequent repurchase behaviour are proposed and empirically tested using data from 55 consumers who patronized a large eastern Cape hypermarket. Results imply that product satisfaction is more related to market place variables than actual search behaviour. Repeat shopping intentions are associated with previous shopping experiences at the particular store which also contributes to product satisfaction. Marketing implications and future research directions are briefly discussed.

S. Afr. J. Bus. Mgmt. 1986, 17: 220-224

In hierdie artikel ondersoek die outeur verbruikerstevredenheid met groter huishoudelike toebehore asook die faktore wat daartoe lei. Hipoteses wat die verband tussen inligtinginwinningsaktiwiteite vooraf en produktevredenheid ondersoek, asook vorige bevredigende ondervindings by 'n spesifieke winkel en gevolglike heraankope, is empiries getoets met 'n steekproef van 55 verbruikers by 'n groot hipermark in die Oos-Kaap. Die resultate impliseer dat produktevredenheid meer verband hou met bemarkingsplek. verwante veranderlikes as met inligtinginwinningsgedrag. Herhaling van koopvoornemens is geassosieer met vorige bevredigende koopervarings by die betrokke winkel wat ook bydra tot produktevredenheid. Bemarkingsimplikasies en toekomstige navorsingsriglyne word ook kortliks bespreek. S.Afr. Tydskr. Bedryfsl. 1986, 17: 220-224

\section{Rousecau}

Department of Industrial and Organizational Psychology, University of Port Elizabeth, P.O. Box 1600,

Port Elizabeth, 6000 Republic of South Africa
Several studies have shown that consumers engage in relatively little information search, even when the financial commitments involved indicate that search may be well justified (Katona \& Mueller, 1955; Claxton, Fry \& Portis, 1974; Newman \& Lockeman, 1975). These researchers found that even for expensive products such as major appliances and furniture, limited information search occurred. Studies carried out in South Africa on information search patterns by hypermarket shoppers revealed similar results (Rousseau, 1982, 1984). Prior to purchase, buyers of small electrical appliances, car accessories and hardware equipment engaged in little overt search at other stores.

Four reasons may explain the low level of information search apart from measurement error (Newman, 1977). (a) Consumers may not perceive information as easily obtainable and hence, do not try to get it; (b) consumers may perceive that information is available but do not obtain it because they do not know how to use it to make a choice; (c) information search may be low because consumers do not think they need it; and (d) consumers may not care, i.e. the decision is a low involvement one.

With respect to the first explanation it is possible that the perceived value of information search exceeds its cost (telephone calls, store visits, exposure to aggressive salespeople). The second explanation suggests that consumers do not realize the significance of certain attributes such as product life cycle in selecting a refrigerator. Thirdly, consumers may feel that they can rely on prior experience based on such factors as previous purchases, information obtained earlier and satisfaction with product and store. Finally consumers may not search much because their choices involve little perceived risk, either financial or social.

The third possibility, namely that prior experiences such as pre-purchase information search and store knowledge may be linked to product satisfaction is the focus of the research reported here. This paper endeavours to assess whether consumer satisfaction or dissatisfaction is related to the amount of information search and more specifically, whether product satisfaction is related to market place satisfaction. A new dimension (post-purchase evaluations) is thus added to a longitudinal study on consumer patterns of information search. The investigation is carried out in the major appliances context - washing machines, stoves, refrigerators and microwave ovens - as these product categories suggest high involvement decision making. 


\section{Conceptual foundation}

Consumer satisfaction/dissatisfaction is generally conceptualized as the outcome of a consumer's subjective comparison of expected and received product attribute levels (Fornell \& Robinson, 1983). The functional relationship between what was expected and what is received has been examined mostly in the context of psychological theory. Examples include discrepancy theory (Gilly \& Gelb, 1982); two-factor theory (Maddox, 1981); and attribution theory (Folkes, 1984).

Gilly \& Gelb noted that discrepancies do in fact exist between what complaining consumers expect from the complaining process and what they then receive. The authors attempt to demonstrate how views of satisfaction/dissatisfaction can be a function of discrepancy between expectations and actual results.

According to two-factor theory, consumer level of satisfaction is independent of the level of dissatisfaction. An individual may simultaneously be very satisfied and dissatisfied. Attempts by Maddox to study satisfaction with clothing along two qualitatively different sets of dimensions, viz. instrumental and expressive values, produced only mixed results for the two-factor notion. The author concluded that the two-factor view complicates the understanding and influencing of consumer satisfaction.

Attribution theory views people as rational information processors who will seek some reason for the purchase after it occurred and may arrive at several explanations: the product performs well, is reliable, safe, good value for money. Attribution approaches predict that the cause inferred for product success or failure, influences how the consumers will respond (Folkes, 1984). The purpose of our research is to investigate this link, to determine the cause of product satisfaction/dissatisfaction by monitoring pre-purchase information search and market place experiences.

Experimental research on brand choice behaviour (Jacoby, Speller \& Kohn, 1974; Westbrook \& Newman, 1978; Kourilsky \& Murray, 1981) has suggested that satisfaction may be related to purchase decision activity. These investigators found that feelings of satisfaction with brand choice increased as respondents were exposed to greater amounts of pre-purchase information and economic reasoning in family budgetary decisions. In another study on consumers' prior experiences and perceptions in auto repair choice (Biehal, 1983), satisfaction increased with external search and with the number of times the repair company had been used previously. Swan (1977) found that satisfaction with a store influenced postshopping attitudes, which in turn influenced intentions to shop again. Westbrook \& Newman (1978) reported greater dissatisfaction amongst consumers who were not highly satisfied with the previous owned appliance as well as amongst first time buyers.

The present study tested three hypotheses all suggested by the literature cited above.

H1. (a) The greater the quantity of information search prior to purchase, the greater the likelihood of product satisfaction.

(b) The smaller the quantity of information search prior to purchase, the greater the likelihood of product dissatisfaction (Jacoby, et al., 1974; Westbrook \& Newman, 1978; Kourilsky \& Murray, 1981).

H2. The higher the degree of satisfaction with previous shopping experience at a particular store, the greater the likelihood of satisfaction with products bought at the store (Biehal, 1983).

H3. The higher the degree of satisfaction with previous shopping experience at a particular store, the greater the likelihood of repeat shopping intentions (Swan, 1977).

\section{Method}

Subject

The subjects were 55 white buyers of major household appliances at a large eastern Cape hypermarket. The sample was taken in the store at point of purchase. Though questions have been raised about the recall method in studying prepurchase behaviour, the author believed that consumers would be able to report more accurately their purchase deliberation immediately after purchase, as memory failure would be minimum.

\section{Measures}

All data are subject to measurement error. An attempt was made to reduce the impact of these errors in various ways. Data on pre-purchase information search were gathered by measures similar to those used by Newman and Rousseau in previous studies (Westbrook \& Newman, 1978; Rousseau, $1982,1984)$. Information source usage was determined by a series of aided recall questions as well as in-store observations. Survey questions designed to detect out-of-store information search focused on the number of stores visited, telephone enquiries made, consultation with friends, family members and recall of newspaper, magazine, T.V. and radio commercials. In-store information search was detected and recorded on an observation schedule. The following activities were observed: reading of store advertisements, physical examination and comparison of products, prices, seeking advice from sales staff and fellow shoppers.

Product satisfaction/dissatisfaction was measured with 12 specific survey questions about respondents' feelings and experiences during the post-purchase period. Respondents rated their product experiences, product expectations and after-sales service on a five-point itemized scale ranging from unhappy to pleased. Satisfaction with previous shopping experiences at the particular store was also measured as part of the post-purchase interview.

The five-point itemized scale was developed from a sevenpoint Likert type scale, tested as a measure for product satisfaction by Westbrook (1980). Three separate studies with durable goods indicated the suitability of the D.T. (delighted terrible) scale for measurement of consumer satisfaction. The measure has reasonable reliability, converges with other rating scales and free response measures. In addition the modified five-point itemized scale, using similar verbal anchor points as the seven-point D.T. scale, was tested for internal consistency. Coefficient alpha was employed to test the reliability of the item sample. Nunnely (1978) stated that coefficient alpha is a very important formula in the theory of reliability. It is so pregnant with meaning that it should be applied routinely to all new tests. A correlation of 0,92 was obtained. An attempt was also made to obtain nomological validity for the instrument by assessing to what extent the measure behaves as it should. Nomological validity is indicated if the measure supports hypothesized relationships between satisfaction and its antecedents and effects (Westbrook, 1980). The approved hypothesis indicates in the direction of nomological validity.

\section{Procedure}

Intercepts of major household appliance purchases were taken from the sales floor at the store. Major household appliances were chosen because they involve discernable purchase decision 
activity and are products for which purchasing problems are suspected. Moreover, the product category entails considerable economic importance. Two postgraduate students acted as field-workers. Each field-worker observed and afterwards interviewed one buyer at a time. Interviews took place after the purchase was made.

Having completed.the interview, respondents received a business reply paid postcard, on which they had to rate their product experiences at home, after using the product for a fortnight and mail it back to the author. Each postcard had a case number which corresponded with the rest of the protocol so that data could be matched for each respondent.

The sample was taken over a three-month period during the first half of 1984 and prior to the increase in G.S.T. and finance charges. As no respondent could be classified as totally dissatisfied with products bought (i.e. gave negative ratings on all items measuring satisfaction/dissatisfaction) the sample was split into satisfied and less satisfied customers. Respondents who had indicated dissatisfaction on six or more of the items on the rating scale were classified as less satisfied.

As a control measure for changes in rating scores owing to a longer period of product exposure, a follow-up procedure was employed six months after the initial ratings were received. A sample comprising of satisfied and less satisfied respondents were asked once more to rate their product experiences on the same rating scale after being contacted by telephone. A correlation coefficient $r=0,71$ ( $d f 38, P<0,01$ ) was found between the ratings in the original and follow-up sample.

\section{Scoring}

An index of information seeking was created similar to that used by Newman \& Westbrook (1978). One point was assigned for one mention of each of these types of activity: reading point-of-sales literature, talking to appliance salespersons, speaking to friends, neighbours or relatives, recall of newspaper or magazine advertisements, and consultation of neutral sources such as consumer reports or instruction booklets prior to purchase. In addition, one point was awarded for each retail outlet visited before buying and one point for each telephone inquiry made. The range of possible scores on the index for pre-purchase information search was from zero to 12 .

Satisfaction was scored by assigning one point for each response per predictor indicating a favourable experience. See Tables la and b for identification of predictor items. Responses to these items were presumed to be monotonically related to the construct of satisfaction. The range of points on the index was $0-12$ for product satisfaction and $0-5$ for store satisfaction.

\section{Results and Discussion}

Using the scoring methods described above, there was clear evidence of satisfaction as favourable responses far outweighed unfavourable ones. Using the percentage of responses that were classified as favourable or unfavourable for each item on the two measures produced the figures in Tables $1 a$ and $b$.

Hypothesis 1. (a) The greater the quantity of information search prior to purchase, the greater the likelihood of product satisfaction. (b) The smaller the quantity of information search prior to purchase, the greater the likelihood of product dissatisfaction.

To test the first hypothesis total information search and product satisfaction scores for each respondent were examined. A Pearson product-moment correlation coefficient test showed no relationship between the two sets of scores, $r=0,13$ (NS)
Table 1a Percentage responses to measures predicting product satisfaction/dissatisfaction

\begin{tabular}{lcc}
\hline & \multicolumn{2}{c}{$\begin{array}{c}\text { Percentage response } \\
\text { (Total 100\%) }\end{array}$} \\
\cline { 2 - 3 } Predictors & Favourable & Unfavourable \\
\hline Performance & 84 & 16 \\
Reliability & 90 & 10 \\
Safety features & 96 & 4 \\
Price evaluation & 94 & 6 \\
Savings owing to product usage & 84 & 16 \\
Product expectations met & 88 & 12 \\
Repurchase as indicator of & & 16 \\
satisfaction/dissatisfaction & 84 & 14 \\
Recommendation to others as & & 2 \\
indication of satisfaction/ & & 4 \\
dissatisfaction & 86 & - \\
After sales service & 98 & 6 \\
Guarantee commitments carried out & 96 & \\
Sales staff attitudes toward problems & & \\
with product & 100 & \\
Management/manufacturer's & 94 & \\
willingness to replace faulty products & & \\
\hline$N$ - 55 & &
\end{tabular}

Table 1b Percentage responses to measures pre dicting store satisfaction/dissatisfaction

\begin{tabular}{lcc}
\hline & \multicolumn{2}{c}{$\begin{array}{c}\text { Percentage response } \\
\text { (Total 100\%) }\end{array}$} \\
\cline { 2 - 3 } Predictors & Favourable & Unfavourable \\
\hline Availability of quality or fashion & & \\
merchandise & 80 & 20 \\
Selection and variety of merchandise & 86 & 14 \\
Price appeal & 72 & 28 \\
Sales clerk service & 64 & 36 \\
Returns and adjustment & 60 & 40 \\
\hline
\end{tabular}

$N=55$

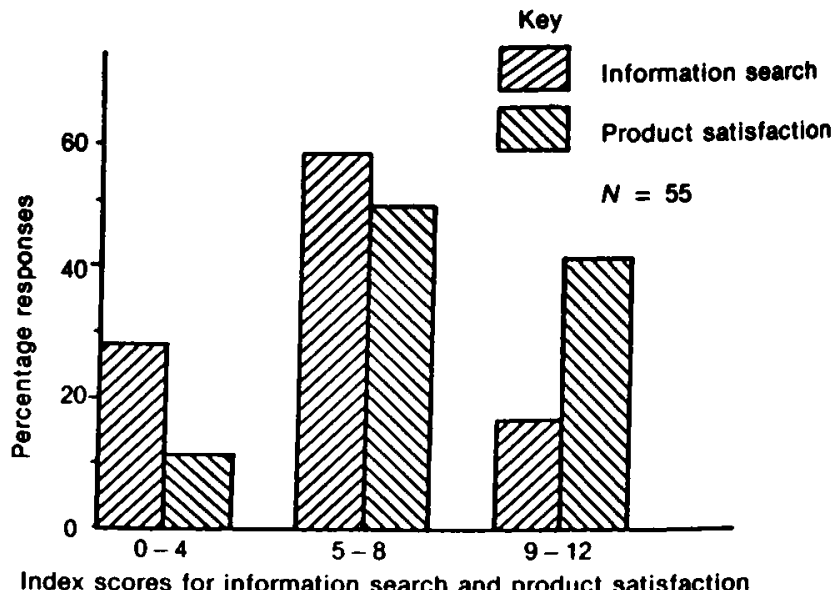

Figure 1 Percentage distribution of information search and product satisfaction score by respondents.

for the total sample. Splitting the sample into satisfied and less satisfied groups produced no significant correlation, $r=$ 0,20 (df $43 \mathrm{NS}$ ) for the satisfied group; $r=-0,15(d f 8 \mathrm{NS})$ for the less satisfied group.

Figure 1 shows the results in summarized form with individual scores grouped in three index categories. The graph 
clearly shows no relationship between information search and product satisfaction. More information search did not result in more product satisfaction and vice versa.

Hypothesis 2. The higher the degree of satisfaction with previous shopping experience at a particular store, the greater the likelihood of satisfaction with products bought at the store.

The second hypothesis was supported. A positive correlation $r=0,39, P<0,01$ was obtained between previous store satisfaction and product satisfaction scores. Table 2 shows that $80 \%$ or more respondents indicated a high level of satisfaction with previous shopping experiences and products bought at the store (were either pleased or mostly satisfied).

Product attributes mainly responsible for the high degree of product satisfaction were performance and reliability. Store attributes which cause satisfactory shopping experiences were mainly availability and selection of merchandise (Tables la and $b$ ).

Table 2 Percentage of responses at each satisfaction level for product and previous store experience

\begin{tabular}{lcc}
\hline $\begin{array}{l}\text { Self reported levels } \\
\text { of satisfaction }\end{array}$ & $\begin{array}{c}\text { Product } \\
\text { purchased }\end{array}$ & $\begin{array}{c}\text { Previous } \\
\text { shopping } \\
\text { experience }\end{array}$ \\
\hline Pleased & 46 & 54 \\
Mostly satisfied & 38 & 26 \\
Mixed & 6 & 16 \\
Mostly dissatisfied & 8 & 4 \\
Unhappy & 2 & 0 \\
Total $(N=55)$ & $100 \%$ & $100 \%$ \\
\hline
\end{tabular}

Hypothesis 3. The higher the degree of satisfaction with previous shopping experience at a particular store, the greater the likelihood of repeat shopping intentions.

The third hypothesis was also supported by the data. A correlation of $r=0,40, P<0,01$ was obtained between previous shopping experiences at the store and repeat shopping intentions. Table 3 shows the proportion of repurchase at each satisfaction level. A $t$ test for significance of differences between proportions of repeat and no repeat shopping intentions was also performed resulting in $t=2,65$ (df 54 , $P<0,05)$.

The findings indicate that expressed satisfaction with a purchase decision process for major household appliances is more a function of store satisfaction than pre-purchase information search. The pattern that emerges suggests that quality of service at the shop, selection and variety of merchandise and price appeal are more important in product satisfaction than actual search. Repeat shopping intentions are

Table 3 Proportion of repurchase at each satisfaction level

\begin{tabular}{lccc}
\hline Satisfaction & $\begin{array}{c}\text { Satisfaction with } \\
\text { previous shopping } \\
\text { experience } \\
(\%)\end{array}$ & $\begin{array}{c}\text { Repeat } \\
\text { shopping } \\
\text { intentions } \\
(\%)\end{array}$ & $\begin{array}{c}\text { No repeat } \\
\text { shopping } \\
\text { intentions } \\
(\%)\end{array}$ \\
\hline levels & 54 & 44 & 6 \\
Pleased & 26 & 22 & 7 \\
Mostly satisfied & 16 & 4 & 11 \\
Mixed & 4 & 3 & 3 \\
Mostly dissatisfied & 100 & 73 & 27 \\
Total $(N=55)$ & & &
\end{tabular}

also in part a function of satisfactory previous shopping experiences.

These findings have important implications for marketers. More attention should be paid to providing pleasant shopping environments. Sales staff should be trained to be informative and supportive when approached by customers in the store. Care should be taken not to provide information overload via media and personal information sources as this may prove threatening and confusing to the average shopper.

Limitations of the study should be mentioned here. Although the findings of the study partially support that of other research in the field (Biehal, 1983; Swan, 1977) it should be borne in mind that the results are based on a relatively small sample. The fact that only a few respondents could be identified as less satisfied may further point to measurement error or unwillingness to give negative responses. The attempt to introduce a control measure of test retest was only partially successful owing to sample attrition. Only $60 \%$ of the original sample could be retrieved in a follow-up procedure.

\section{Conclusion}

Keeping these limitations in mind, some tentative conclusions may be drawn. First, future research needs to incorporate more fully consumers' prior shopping experiences and store loyalties in studies of product satisfaction. Secondly, future research should focus not only on external sources of prepurchase information search (i.e. from the outside environment) but also on internal sources (experiences stored and used in the memory) when attempting to relate search behaviour to consumer satisfaction. Finally, future research needs to examine more fully consumers' tendencies to respond favourably to survey questions dealing with satisfaction/dissatisfaction. Unlike laboratory experiments where prior experiences can be manipulated to a degree (Bettman \& Park, 1980), field studies have to rely on self-reported data which implies that future research will need to consider carefully, what aspects of prior experiences need measuring, how these measures can be reliably and validly obtained and when in the decision process they should be introduced (i.e. intercepts on the store floor, personal home interviews or mail questionnaires).

Overall, the results of this research do support several of the hypothesized relationships based on attribution theory.

\section{Acknowledgement}

The research on which this study is based was funded by the Human Sciences Research Council. The author wishes to thank Sylvia Miller and Bill Birkenbach for valuable assistance and advice.

\section{References}

Bettman, J.R. \& Park C.W. 1980. Effects of prior knowledge and experience and phase of the product choice process on consumer decision making: A protocol analysis. J. Consumer Res., vol. 7, $234-248$.

Biehal, G.J. 1983. Consumers prior experiences and perceptions in auto repair choice. J. Mark., vol. 47, 82-91.

Claxton, J.D., Fry, J.N. \& Portis, B. 1974. A Taxomony of prepurchase information gathering patterns. J. Consumer Res., vol. $1,35-42$.

Folkes, V.S. 1984. Consumer reactions to product failure. An attributional process. J. Consumer Res., vol. 10, 398-409.

Fornell, C. \& Robinson, W.T. 1983. Industrial organization and consumer satisfaction dissatisfaction. J. Consumer Res., vol. 9, $403-411$.

Gilly, M.C. \& Gelb, B.D. 1982. Post-purchase consumer processes and the complaining consumer. J. Consumer Res., vol. 9, $323-327$

Jacohy, J., Speller, D.E. \& Kohn, C. 1974. Brand choice as a 
function of information load. J. Mark. Res., vol. 11, 63-69. Katona, G. \& Mueller, E. 1955. A study of purchase decisions in consumer behaviour. In: Consumer behaviour: The dynamics of consumer reaction. Clarke, L.H. (Ed). New York: New York University Press.

Kourilsky, M. \& Murray, T. 1981. The use of economic reasoning to increase satisfaction with family decision making. $J$. Consumer Res., vol. 8, $183-188$.

Maddox, R.N. 1981. Two factor theory and consumer satisfaction: Replication and extention. J. Consumer Res., vol. 8, 97- 102.

Newman, J.W. 1977. Consumer external search. Amount and determinants. In: Consumer and industrial buying behaviour. Woodside, A.G., Sheth, J.N. \& Bennett, P. (Eds). New York: North Holland.

Newman, J.W. \& Lockeman, B.D. 1975. Measuring pre-purchase information seeking. J. Consumer Res., vol. 2, 216-221.
Nunnely, J.C. 1978. Psychometric theory. New York: McGraw-Hill.

Rousseau, D. 1982. A study on pre-purchase information search by consumers. S. Afr. J. Psychol., vol. 12, 19-23.

Rousseau, D. 1984. Patterns of information search among semidurable goods buyers. S. Afr. J. Psychol., vol. 14, 1-6.

Swan, J.E. 1977. Consumer satisfaction with a retail store related to the fulfilment of expectations on an initial shopping trip. In: Consumer satisfaction dissatisfaction and complaining behaviour. Day, R.L. (Ed). Bloomington: Indiana University School of Business.

Westbrook, R.A. 1980. A rating scale for measuring product service satisfaction. J. Mark., vol. 44, 68-72.

Westbrook, R.A. \& Newman, J.W. 1978. An analysis of shopper dissatisfaction with major household appliances. J. Mark. Res., vol. XV, 456-466. 